\title{
The impact of Pseudomonas syringae bacteria on the plant pathogenic fungi and cherry plants
}

\author{
Marina Maslova ${ }^{1}$, Ekaterina Grosheva ${ }^{1}$, Ivan Shamshin ${ }^{1}$, Anna Kuznetsova ${ }^{2 *}$, \\ and Alexander Fedorenko ${ }^{2}$ \\ ${ }^{1}$ Federal State Budgetary Educational Institution of Higher Professional Education "Michurinsk State \\ Agrarian University", 101, Internatsionalnaya Str., Michurinsk, Tambov Region, Russia, 393760 \\ ${ }^{2}$ Federal State Budgetary Scientific Institution «North Caucasian Federal Scientific Center of \\ Horticulture, Viticulture, Wine-making», 39, 40 let Pobedy Str., Krasnodar, Krasnodar Territory \\ Russia, 350901
}

\begin{abstract}
The investigations are made of cherry biological peculiarities and disease excitants composition. The domination of necrotrophic fungi and Pseudomonas syringae van Hall bacteria in pathocenosis is shown. The fact of microbiota associative lesion of plants is established. The antagonist action of isolated bacterium in relation to Cytospora leucostoma (Pers.) Sacc., Alternaria alternata Keissl., Fusarium oxysporum Schlecht., Monillia cinerea Bonord is detected. The character of isolated bacterium metabolites, pathogenic fungi and their association effect on a host-plant is established. The ability of bacterium to lower the activity of phytotoxins secretion in fungi when cultivated together is identified. It has been found that it is the fungal pathogens causing the development of die-back in cherry in investigated gardens, whereas $P$. syringae bacterium, when in latent state, plays a part of protector and permits to suppress the development of fungal infection. Taking into account the fact that this bacterium is pathogenic, the works of advanced breeding for resistance of the horticultural crops to bacterial blight are recommended.
\end{abstract}

\section{Introduction}

At the present time the increase in conditionally pathogenic microorganisms is noted in mycocenoses of the horticultural crops. The parasitic activity of Alternaria, Fusarium fungi has grown [1]. The phenomenon of the microorganisms' complexes formation and microbiota associative lesion of plants becomes not infrequent, which is a reason of spot blights, die-back and wilting not only of separate shoots, but of all plant as a whole [2-4].

It has been generally accepted for a long time that the tissues of plants are absolutely sterile. But the vascular system of plants has been found to be constantly inhabited with the microorganisms [5-7]. As a rule, no pathogenic microorganisms fall under definition of endophytes. But the latest investigations of some authors have shown the relations of plants and endophytes to have much wider range, varying from useful to pathogenic action, and this is the reason why Hardoim and colleagues (2015) put forward an assumption that

\footnotetext{
*Corresponding author: anpalkuz@mail.ru
} 
perhaps the term "endophyte" has to refer only to their habitat, rather than to their functions $[8-12]$.

The well established trends in formation of pathocenosis of the stone fruit crops garden have necessitated the regular phytosanitary monitoring in an effort to identify the most destructive pathogenic objects, to study the peculiarities of their biology, development dynamics, character of interaction with each other and with a host-plant, which is necessary for the adequate comprehension of the structural elements interaction mechanisms in the "host - parasite" system and elaboration of measures to control the diseases of the stone fruit crops.

\section{Materials and methods}

The work has been done at the premises of Fundamental scientific and research laboratory "Biophotonica" and laboratory of the fruit plants molecular genetic analysis of the Federal State Budgetary Educational Institution of Higher Education "Michurinsk State Agrarian University" on the stone fruit crops genetic collection of I.V. Michurin Federal Scientific Centre in 2002-2019.

The route examination of the cherry gardens was undertaken in the course of investigations to identify the local areas of disease development.

The isolation of endophytic microorganisms was carried out through inoculation of sterile explants on a solid growing medium. The explants were sterilized, dipping them into 96 percent alcohol and burning in the flame of spirit stove. The microorganisms, isolated from the plant explants, were studied further in conditions of pure cultures. With this object in mind the liquid and solid growing media were used: potato dextrose agar and Czapek's medium [13].

The identification of microorganisms was carried out by the cultural-morphological characters, as well as by the method of PCR-diagnostics with the use of specific primers.

The DNA isolation from the cells of bacteria was carried out by the method of chloroform-phenol extraction following the 24-hour cultivation on King B medium [14].

The identification required the use of molecular markers, created on the basis of hrpL genes of Pseudomonas bacteria analysis. The primer pairs were synthesized by ZAO Syntol (Moscow, Russia). See Table 1 for the sequence.

Table 1. The sequence of primer pairs, used in the work

\begin{tabular}{|c|l|c|}
\hline Name & \multicolumn{1}{|c|}{ Sequence 5'-3 } & Original author \\
\hline PapF & AACCACGCCAACCATCGTCA & Kerkoud,2002 \\
\hline PapR & GCGATACATTTTGCGAAAGTGGTTG & \\
\hline
\end{tabular}

The reaction mixture composition for PCR (15 $\mu$ l volume): $20 \mathrm{ng}$ of DNA, $1.5 \mathrm{mM}$ dNTP, $2.5 \mathrm{mM} \mathrm{MgSO} 4,10 \mathrm{pM}$ of each primer, 1 unit of Taq polymerase and $10 \times$ standard PCR-buffer. The reaction was carried out with the use of SimpliAmp (Life Technology) instrument. The program comprised the stages as follows: initial denaturation at $92{ }^{\circ} \mathrm{C}$ for 2 min; 35 cycles at $92{ }^{\circ} \mathrm{C}$ for $1 \mathrm{~min} ; 52{ }^{\circ} \mathrm{C}$ for $1 \mathrm{~min} ; 72{ }^{\circ} \mathrm{C}$ for $1 \mathrm{~min}$; final elongation for 2 $\min$ at $72{ }^{\circ} \mathrm{C}[15]$.

The products of amplification were divided by means of electrophoresis in 2 percent agarose gel. Thereafter the gels were analyzed in UV light with the use of transilluminator.

In order to obtain the fermentation broth filtrate of the microorganisms under study they were cultivated on the liquid Czapek's medium during a month in $500 \mathrm{ml}$ Ehrlenmeyer's flasks at the temperature of $22-24{ }^{\circ} \mathrm{C}$. The obtained metabolite solution was separated from living cells, passing through the membrane filter ("Millipore" $0.22 \mu \mathrm{m}$, France). 
The antagonist action of bacterium metabolites against the fungal pathogens was determined from the down growth of testing culture on the solid growing media with 10 percent contents of bacterial fermentation broth filtrate [15].

The character of the studied microorganisms impact on a host-plant was estimated with the use of the cherry leaves and leave cutouts, which were placed in containers filled with solution of microbial metabolites in concentrations: $2.5-30.0$ percent. The controls were the specimens, incubated in water. The lesion of plant tissues was estimated visually on a scale from one to five: 0 - negative lesion; 1 - very mild lesion (the chlorotic or necrotic spots are singular); 2 - mild lesion (less than 10 percent of leaf surface is affected with necrosis or up to 25 percent - with chlorosis; 3 - medium lesion (necrosis from 11 to 25 percent or chlorosis from 26 to 50 percent); 4 - severe lesion (necrosis from 26 to 50 percent, chlorosis more than 50 percent); 5 - very severe lesion (necrosis more than 50 percent).

The calculation of the cultural filtrate toxical activity was made according to a formula:

$$
\mathrm{S}_{\mathrm{t}}=100-\mathrm{L}_{\mathrm{o}} \times 100 \% / \mathrm{L}_{\mathrm{k}},
$$

where $\mathrm{S}_{\mathrm{t}}$ - toxicity level (in percentage terms);

$\mathrm{L}_{\mathrm{o}}$ - condition of leaves in experiment (in points);

$\mathrm{L}_{\mathrm{k}}$ - condition of leaves in a control (in points).

The effect of the microorganisms cultural filtrate on the chlorophyll-containing tissues of a host-plant was estimated by their photosynthetic activity on PAM - Junior chlorophyllfluorimeter (Germany, Heinz Waiz GmbH).

The intensity of the stone fruit plants' die-back development was estimated under field conditions by the visual observation as a percentage of the crown dead part from its total volume. The investigations involved 5 trees of each of 10 varieties.

The statistical processing of obtained data employed the use of standard computer programs Microsoft Office Excel 2007.

\section{Results and discussion}

Testing for endophytic microbiota of the cherry branches and leaves with the symptoms of lesion and without showed Pseudomonas syringae van Hall bacterium and fungal microbiota with domination of Cytospora leucostoma (Pers.) Sacc., Alternaria alternata Keissl., Fusarium oxysporum Schlecht., Monillia cinerea Bonord to isolate from the plant explants. The formation of the microorganisms' associative complexes, able for coexistence in internal tissues of a host-plant, is established as a fact. Since the fungal pathogens are encountered in a complex with bacterium, the disease diagnostics is complicated in connection with distortion of specific symptoms, as this takes place the control of pathogenic microorganisms becomes difficult in connection with their various groups affiliation, both systematically and according to their trophic status.

The investigations engaged Pseudomonas syringae pv. syringae ICMP 9067 strain, isolated from cherry, which is included into the microorganisms collection of the Federal State Budgetary Institution "All-Russian Plant Quarantine Centre".

Belonging of bacterial strains, used in investigations, to $P$. syringae species is evidenced by amplification of DNA fragment 242 bp in size with specific primers, which is illustrative of available $h r p L$ gene molecular marker, associated with functioning of Type III secretion in this bacterium (Fig. 1) $[16,17]$.

The inoculation of the C. leucostoma, A. alternata, F. oxysporum, M. cinerea fungal testers on the media with $P$. syringae toxin has established its antagonist action in relation to a series of phytopathogens. The point assessment of the fungal colonies' condition showed their growth power to be lower in the media with $P$. syringae bacterium 
metabolites, as compared with a test medium (free of bacterial metabolites). In the fungal testers under study the prominent features of degradation (mycelia lysis, lack of sporulation, etc.) were in evidence. The highest level of fungicidal and fungistatic activity was shown by bacterium as regards A. alternata (At $=65.6$ percent) and C. leucostoma (At=75.0 percent) fungi. In which case $F$. oxysporum and $M$. cinerea appeared to be more resistant to the action of bacterial metabolites, the toxical activity of which in relation to these pathogens was 59.6 and 50.9 percent respectively.

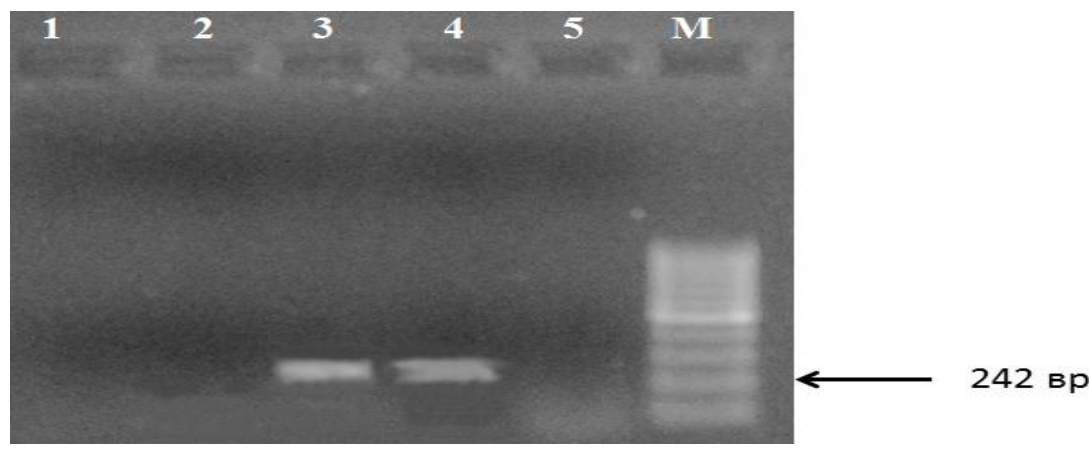

1 - Bacillus subtilis M - 22 VIZR;

2 - Bacillus subtilis VIZR - 10;

3 - Pseudomonas syringae pv. syringae ICMP 9067;

4 - Pseudomonas syringae pv. syringae ICMP 9032;

5 - Pseudomonas fluorescens AP - 33;

$\mathrm{M}$ - DNA size markers $100 \mathrm{bp}$

Fig. 1. Results of bacterial DNA amplification with Pap1/Pap2 primer

Since the various microorganisms are isolated from the cherry plants with the symptoms of lesion and without, the necessity arises to determine the character of their metabolites' action on the host. There is established stimulatory action of 2.5 and 5.0 percent $P$. syringae bacterium cultural filtrate solutions in regards to the studied plants. The necrotization degree mean score of the cherry leaves, incubated for 6 days in microbial metabolites solutions, was 1.45 and 1.56, respectively, whereas in control this index was 1.9.

In experiment involving the metabolites of $M$. cinerea, A. alternata and $F$. oxysporum plant pathogenic fungi the necrotization of leaf tissues already in solution at 2.5 percent concentration made 2.2 points, exceeding reference value. More than 3.0 points lesion of the plant tissues was noted in solutions of bacterium cultural filtrates and fungal pathogens at 10.0 percent concentration and more. The analysis of $P$. syringae bacterium and $M$. cinerea, A. alternata, F. oxysporum fungi fermentation broth filtrate effect in relation to a host-plant showed the phytotoxicity of micromycetes be pronounced to the fullest extent as compared with bacterium. On the 6th day of incubation the photosynthetic activity of leaf tissues in a 10 percent solution of $P$. syringae bacterium metabolites was 0.69 c.u., therewith in the test engaging the solutions of cultural filtrates of the A. alternata, $M$. cinerea and $F$. oxysporum fungal pathogens the indices were equal to $0.43 ; 0.42$ and 0.28 c.u. respectively.

In laboratory conditions a comparative study was conducted on phytotoxicity of metabolites of the pure microorganisms' cultures and artificially created associations. The combined cultivation of $P$. syringae bacterium and A. alternata, M. cinerea, F. oxysporum fungi on the liquid growing media established the reduction in phytotoxicity of metabolites of associations as compared with the filtrates of pure cultures. The incubation of the leaf cutouts during 6 days in the solutions of the toxical metabolites of the artificially created 
microbial associations ( $P$. syringae + A. alternate; $P$. syringae $+M$. cinerea $;$ P. syringae + $F$. oxysporum) was followed by significant increase in photosynthetic activity of the plant tissues, as compared with the variants of the fungi pure cultures and was $0.56 ; 0.51$ and 0.37 c.u. respectively. It is associated with reduction in phytotoxical activity of fungi under the influence of P.syringae bacterium (Fig. 2).

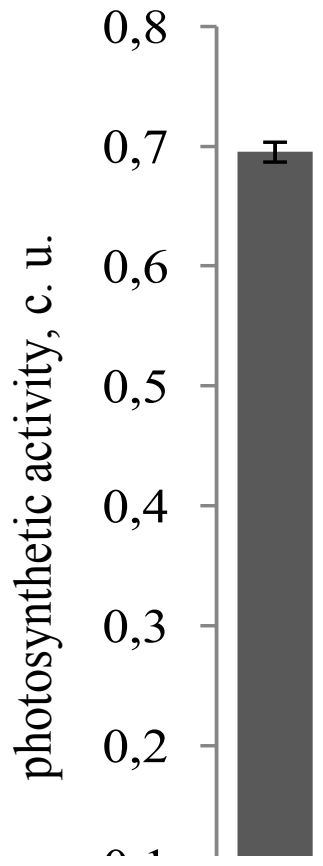

II - A. alternata,

III - P. syringae + A. alternata,

IV - M. cinerea,

$\mathrm{V}-$ P. syringae + M. cinerea,

VI- $F$. oxysporum

VII - P. syringae $+F$. oxysporum
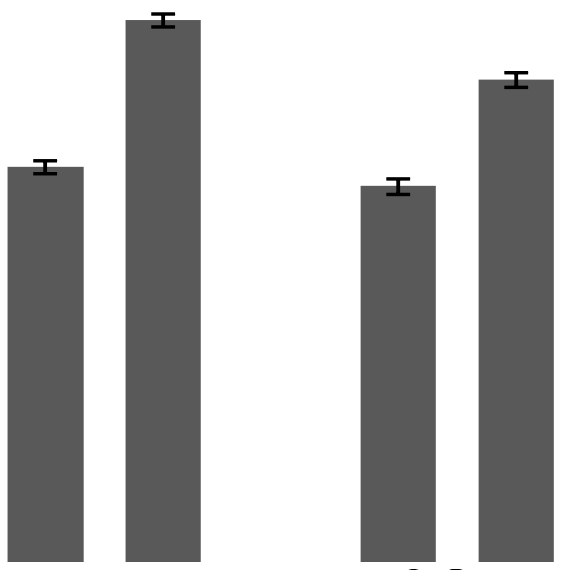

I - P. syringae,

Fig. 2. The photosynthetic activity mean values of cherry leaves incubated in toxic metabolites of microorganisms and their associations $( \pm$ standard error)

The assessment of endophytic microbiota composition in cherry plants varying in degree of die-back permitted to establish the direct dependence of this disease development intensity on endophytic fungi testing frequency (correlation coefficient $(r)=0.77$ ) and the reverse character of dependence on the occurrence percentage of endophytic bacterial microbiota $(r=-0.89)$ (Table 2). 
Table 2. The frequency of endophytic microorganisms occurrence as a function of degree of blight in cherry varieties

\begin{tabular}{|c|c|c|c|}
\hline \multirow{2}{*}{ Varieties } & \multicolumn{2}{|c|}{$\begin{array}{c}\text { Frequency of endophytic } \\
\text { microorganisms occurrence (\%) }\end{array}$} & \multirow{2}{*}{$\begin{array}{c}\text { Degree of } \\
\text { blight (\%) }\end{array}$} \\
\cline { 2 - 3 } & $\begin{array}{c}\text { bacterial } \\
\text { microbiota }\end{array}$ & fungal microbiota & \\
\hline Rovesnitsa & $77.2 \pm 2.6$ & $6.2 \pm 1$ & $3.2 \pm 0.7$ \\
\hline Kharitonovskaya & $88.7 \pm 0.7$ & $1.0 \pm 0.5$ & $5.1 \pm 0.2$ \\
\hline Nakhodka Skripnikova & $84.4 \pm 1.2$ & $7.3 \pm 1.9$ & $5.2 \pm 0.7$ \\
\hline №1 & $87.9 \pm 1.7$ & $6.2 \pm 1.5$ & $10.6 \pm 0.8$ \\
\hline Turgenevka & $87.0 \pm 2.5$ & $3.3 \pm 1.3$ & $14.3 \pm 2.7$ \\
\hline Feya a & $82.5 \pm 1.4$ & $2.5 \pm 0.2$ & $15.2 \pm 1.2$ \\
\hline Romantik & $70.0 \pm 1$ & $8.6 \pm 1.2$ & $22.4 \pm 3.1$ \\
\hline Prevoskhodnaya Ven'yaminova & $67.8 \pm 1.4$ & $14.8 \pm 1.5$ & $23.2 \pm 2.1$ \\
\hline Shokoladnitsa & $64.7 \pm 5.7$ & $8.0 \pm 2.8$ & $35.5 \pm 4.2$ \\
\hline Zhukovskaya & $42.7 \pm 6.6$ & $25.3 \pm 9.3$ & $45.7 \pm 3.1$ \\
\hline mean value \pm standard error & \multicolumn{3}{|}{} \\
\hline \multicolumn{2}{|l|}{} \\
\hline
\end{tabular}

\section{Conclusion}

Thus, this is fungal microbiota, which is a reason of the die-back development in cherry plants in the gardens under investigation. It is important to emphasize that $P$. syringae bacterium is able to suppress the dangerous fungal pathogens thanks to fungicidal and fungistatic toxins and prevent the development of diseases they cause. However, absent the overt symptoms of bacterial lesion on cherry the great caution should be addressed to systemic presence of $P$. syringae bacterium in asymptomatic plants, since there is danger of bacterial blight outbreak on the change of environment conditions and suppression of the plants' protective properties. In connection therewith the necessity arises to run the works for advanced breeding, including the selection of cherry forms and varieties from available assortment and creation of the new genotypes resistant to this bacterium.

The work is executed within the boundaries of government order given by the Russian Federation Ministry of Agriculture from the federal budget resources.

\section{Reference}

1. I.G. Mishchenko. The achievements of science and engineering in agrobusiness. 33, 17-19 (2017) https://cyberleninka.ru/article/n/osnovnye-izmeneniya-v-mikopatosistemahkostochkovyh-kultur-v-sovremennyh-sredovyh-usloviyah-krasnodarskogo-kraya/viewer

2. N.D. Romanenko, S.B. Tabolin. Russian parasitological journal. 3, 130-137 (2014) https://www.elibrary.ru/item.asp?id=22025604

3. C.M. Guennoc, C. Rose, J. Labbé, A. Deveau. BioRxiv. 130740 (2017) https://www.biorxiv.org/content/10.1101/130740v1

4. F. Wemheuer, B. Wemheuer, R. Daniel, S. Vidal. Scientific reports. 1, 1-14 (2019) https://www.researchgate.net/publication/336210431

5. P. Frey-Klett, P. Burlinson, A. Deveau, M. Barret, M.Tarkka, A. Sarniguet. $\begin{array}{lllll}\text { Microbiol. } & \text { Mol. } & \text { Biol. 4, 583-609 } & \text { (2011) }\end{array}$ https://www.researchgate.net/publication/51839806
6. C.W.
Bacon
J.F. White Symbiosis.
$\mathbf{1 - 3}, \quad 87-98$

https://www.researchgate.net/publication/301725689 
7. A. Muthukumar, R. Udhayakumar, R. Naveenkumar Endophytes: Crop Productivity $\begin{array}{llll}\text { and } \quad \text { Protection. } & \text { Springer. } & \text { 133-161 }\end{array}$ https://www.researchgate.net/publication/321053577

8. P.R. Hardoim, J.D. Molecular Microbial Ecology of the Rhizosphere, 405-411 (2013)

9. P.R. Hardoim, L.S. Overbeek, G. Berg, A.M. Pirttilä, S. Compant, A. Campisano, M. Döring, A. Sessitsch. Microbiol. Mol. Biol. Rev. 3, 293-320 (2015) https://www.researchgate.net/publication/279513140

10. E. Busby, M. Ridout, G. Newcombe. Plant Molecular Biology. 90, 645-655 (2016) https://www.researchgate.net/publication/286445604

11.J.F. White, C. W. Bacon. Biotechnology of endophytic fungi of grasses (2018) https://www.researchgate.net/publication/323991040

12. K. Swarnalakshmi, S. Rajkhowa, M. Senthilkumar, D. W. Dhar. Microbial Interventions in Agriculture and Environment. Springer. 263-287 (2019) https://link.springer.com/chapter/10.1007/978-981-32-9084-6_12

13. Tomaž Rijavec, et al. Canadian journal of microbiology. 53, $802-808$ (2007) https://www.researchgate.net/publication/6171363

14. M.H. Abdelhai, H.A.M. Hassanin, X. Sun Am. J. Biosci. Bioeng. 4, 1-8 (2016) https://www.researchgate.net/publication/304339104

15. M.V. Maslova, E.V. Grosheva. International scientific ecological forum of youth "Ecobaltica": collection of research papers, 45-51 (2017) https://www.ggau.by/prints/konferency

16. M. Kerkoud, C. Manceau, J.P. Paulin. Phytopathology. 10, 1077-1083 (2002) https://www.researchgate.net/publication/23408596_Rapid_Diagnosis_of_Pseudomonas_sy ringae_pv_papulans the Causal_Agent_of_Blister_Spot_of_Apple_by_Polymerase_Chain Reaction_Using_Specifically_Designed_hrpL_Gene_Primers

17. Y. Xie, X. Shao, X. Deng. Environmental microbiology. 21, 4465-4477 (2019) https://www.researchgate.net/publication/335151843_Regulation_of_Type_III_Secretion_S ystem_in_Pseudomonas_syringae 